\title{
An Assessment of Social Return on Investment Comparing Agroforestry System to Monocropping System in Uttaradit Province Thailand
}

\author{
Chichaya Changrian, Thavatchai Phimpho, and Sukajiradet Alongkorn
}

\begin{abstract}
This research aims to compare the social return on investment (SROI) of Long LapLae Durian farming in an agroforestry system and a mono-crop system in Uttaradit, Thailand. A purposive sampling approach was employed in this study. The population of the study was 8 households adopting agroforestry practices and 1 household adopting a monoculture practice in Ban Dan Na Kham Subdistrict, Muang District, Uttaradit Province, Thailand. The data were collected through interview forms and were analyzed using an SROI analysis calculated by taking social impact values derived from Long-Laplae Durian farming divided by its cost in the crop year 2017-2018. The values of both practices obtained were then compared. The opportunity cost was used to measure SROI instead of financial cost which comprised of having freedom to farm, living together with family members and relatives, food safety, good community relationship, knowledge exchanges, and the costs of activities arisen in durian farms. The results revealed that the SROI of durian farming in an agroforestry system was 98.33: 1; while the SROI of durian farming in a monocropping system was 66.47: 1 , they would receive social impacts valued at 66.47 baht in return. This showed that the SROI of the agroforestry system was 31.86 baht higher than that of the monocropping farming. Food safety as well as living together with family members and relatives was not founded in the social impacts of the monocropping system. Therefore, agroforestry farming yielded social values to the community by promoting food safety and living together with family members. The government policy should promote agroforestry practices for economic and social development rather than promoting a mono-cropping practice which focuses on increasing the crop yields leading to only higher incomes.
\end{abstract}

Index Terms-Social return on investment, agroforestry system, monocropping system, long laplae durian.

\section{INTRODUCTION}

Uttaradit is a province located in northern Thailand. It is characterized by 3 types of topography: alluvial plains, valley and wavy slope plains, as well as highlands and mountains. Half of the land in the province is highlands and mountains, with 400-1,000 meters of altitude in the north and east of the province, especially in Ta Pla District, Laplae District, and some parts of Muang District. People living in the highland and mountain areas are fruit growers who have adopted local

Manuscript received January 11, 2020; revised March 28, 2020. This work was supported in part by the Uttaradit Rajabhat University (URU) and Thailand Science Research and Innovation (TSRI) under Grant TSRI $026 / 2560$.

Chichaya Changrian, Thavatchai Phimpho, and Alongkorn Sukajiradet are with Faculty of Management Science, Uttaradit Rajabhat University (URU), 53130 Thailand (e-mail: cchangrian@ gmail.com, nonny16@ hotmail.com, alongkorn18@ gmail.com). wisdom in planting fruit trees among other indigenous trees in the forests or in the high plain areas. The economic crops are Monthong durian, Lin Laplae durian, Long Laplae durian, langsat, longan, cashew nuts, mangosteen, marian plum, rambutan, and galangal. Long Laplae durian is the most important economic crop and is widely planted since this kind of durian has a mild taste, creamy texture, small seed, and a very mild scent. The small durian fruit is about 1-1.5 kilograms, and its price is about $80-150$ baht a kilogram. Its price is sometimes as high as 300 baht for a kilogram if the fruit yields are less than the demands. Because of the high returns, farmers in Laplae District have increasingly planted more durians in monocropping systems, resulting in cutting down other trees such langsat trees since the prices of langsat fruits have been only 10-15 baht a kilo. Cutting down indigenous trees had led to an imbalance in the local forests and caused landslides in 2006, resulting in losses which cost about 800 million baht.

This study came from the situation which farmers in Ban Dan Na Kham Subdistrict have rising interests in farming in a monocropping system. These farmers have been adopting farming in an agroforestry system, but they have witnessed that durian farmers in Mae Pool Subdistrict that adopted monocropping farming practices have dramatically become wealthier. Besides, the farmers of Rayong Province, which have bought land in the high plains areas in Ban Dan Na Khan Subdistrict and planted durian in a monocrop system have become wealthier. This was a significant incident which caused other farmers to change their farming practices from the agroforestry to monocropping approach. Developing fruit production, and marketing for these farmers in the agroforestry system is important to generate higher incomes while preserving the forest's condition and the environment. According to [1], the theoretical idea show agroforestry systems are performing better than monocropping approach as they are environmentally friendly, socially reasonable and economically feasible through diversification of input and output. Uttaradit Rajabhat University in collaboration with Ban Dan Na Kham Subdistrict Administrative Organization have worked together on this research program which was funded by the Thailand Science Research and Innovation (TSRI) office.

This study has tried to find out how much social return on investment does the durian farming in both agroforestry and monocropping practices have. It aims to compare the SROI between the two practices. The findings would benefit the Ban Dan Na Kham Subdistrict Administrative Organization and other related government sectors to formulate policies that promote a farming practice which benefits the farmers to 
gain higher incomes while preserving the forest condition. In addition, the results of this study could be publicized to benefit other scholars around the world that are interested in this field of research.

\section{LITERATURE REVIEW}

Agroforestry and monocropping practices were reviewed and compared against each other. In addition, the theory of Social Return on Investment (SROI) was also studied.

According to [2], have examined the estimation of the economic and social values of agroforestry and monocropping systems in Guilan province in Iran. The data about the social and economic issues were collected through questionnaires and were analyzed to find out the internal rate of return (IRR), profitability index (PI), cost and benefits, and net present value (NPV). The data from agroforestry and monocropping practices were then compared in terms of economic and social issues. It was found that the agroforestry farming yielded higher incomes than those of monocropping farming in the area studied. In terms of social issues, the agroforestry practice generated a good relationship among the people in the society.

According to [3], studied about the social return on investment (SROI) of a social enterprise: the case study of crab bank(s) in Chumphon Province. The unit analysis of the study was the outcomes of the crab bank. The result revealed that the impact value chain comprised of inputs, activities, outputs, outcomes and impacts. The impacts were calculated from the outcomes on social changes. It was found that there was no deadweight (loss). The stakeholders who had received outcomes and impacts on a project are members of the crab bank in Chumphon Province, non-members of the crab bank, Subdistrict Administrative Organization, a group of fishermen in other areas, crab merchants in the area, government sectors, and private sectors. Social outcomes were interpreted to financial values in the period of a 7-year investment in the crab bank. It was reported that the SROI ratio of the project was 58.82: 1, which means every 1 baht of investment, the crab bank yielded social impacts valued at 58.82 baht in return.

According to [4], studied the SROI of accommodation businesses: a case study of Hotels in Bangkok and Bang Nam Pheung Homestay. An in-depth interview of related informants and the observation of hotels employed social responsibility and Bang Nam Pheung Homestay adopted a sufficiency economy philosophy as the methods of data collection. It was found that the main stakeholders of hotels businesses were the executives, employees, and villagers living in the nearby areas. The SROI was then analysed. The social value was analysed and interpreted to financial values. The hotels organized activities according to the social responsibility approach while community enterprises organized activities according to the sufficiency economy philosophy which is described as the following:

The hotels in the area which have run their businesses based on a socially responsible approach have done several activities that resulted in a decrease of expenses in terms of social impacts which were interpreted to financial values and which were categorized according to the main stakeholders in 3 groups: 1) For the hotels, the cost of water and electricity bills were decreased; 2) For the community and environment, greenhouse gases from wastewater treatment were reduced, people's health was not destroyed by the polluted water sources in the community, and raw materials used to manufacture paper and plastic bags were decreased; and 3) For Bangkok, waste management costs were also decreased. The financial values were used to calculate a 5-year operation with a 4 percent discount rate. The impacts arisen from outcomes were developed during the study both in terms of deadweight and attribution. Furthermore, sensitivity analysis was carried out with different discount rates while the SROI ratio was revealed as 4.43: 1 .

Community enterprises that have run their business with the adoption of the sufficiency economy theory have created social impacts which were interpreted to financial values as cost savings. These values were categorized according to the main stakeholders as 1) Homestay owners could save the cost of chemicals for cleaning; 2) Bang Nam Pheung Sub-district Administrative Organization could save costs for community support which was received from homestay businesses, and the cost of waste management; 3) Paddle boat entrepreneurs could have higher incomes; 4) the community, environment, and people's health were better because of having safe water sources and less greenhouse gas emissions. Financial values were employed to interpret the social impacts over a 7-year operation with a discount rate at 4 percent. Development of social impacts on the outcomes were conducted, both for deadweight and attribution. Additionally, a sensitivity analysis with different discount rates was carried out and revealed the SROI to be at 4.43: 1 ..

\section{Methodology}

Stage 1: Indicate the boundaries for the study (Delimitation) which was Moo (village) no. 6 in Ban Dan Nakham Subdistrict, Muang Uttaradit, Uttaradit Province; and give the definition for agroforestry and monocropping practices as follows:

Durian farming in the agroforestry system is the practice of having durian trees planted among the indigenous trees which is comprised of 3 vertical layers with 50 percent of the indigenous trees, 30 percent of Long Laplae durian, and 20 percent of the forest floor or at the ratio of 50:30: 20 .

Durian farming in a monocropping system is the practice of planting durian separately from other kinds of plants.

Stage 2: Design interview forms and test the forms under the social impact value chain concept which is comprised of the expenses from farming Long Laplae durian, social impacts of the farming, social impact indicators, and financial value.

Stage 3: Use the interview form to interview the selected informants through a purposive sampling method.

Stage 4: Analyze the data to find out the financial value of the social impacts from social impact indicators of the agroforestry durian farming system as presented in Table I and the monocropping durian farming system as presented in Table III.

Stage 5: Improve the financial value of the social impacts on the stakeholders by adjusting the deadweight and attribution.

5.1 Adjustment of deadweight (loss) through indicating a 
percentage from the estimated interview-data with use of criteria from According to [5].

The deadweight which is over zero percent means there previously was no social impacts. The social impacts resulted from durian farming.

5.2 Adjustment of impact values of performance (Attribution) was carried out by indicating the percentage from estimated interview-data and the criteria from According to [5].

Adjustment is at 100 percent if the whole social impacts result from the durian farmers, not from anybody else.

Adjustment is at 50 percent if the social impacts resulted from the durian farmers as much as from other parties.

Stage 6: Estimate the social impacts of the durians over 20 years, by use of social impact value in the crop year 2017-2018 as a base year since Long Laplae durian trees yield the fruits when they are 5 years old up until they are 20 years old. The estimated social impacts under the growth rate of GDP in the agricultural sector are at 1.09 percent According to [6], (TDRI 2017) and indicate the discount rate for the whole project length, which is 20 years, from the loan interest at 7 percent.

Stage 7: Calculate the SROI according to the following formula from According to [7].

\section{SROI $=$ The present value of all social outcomes (per rai) Value of all activity expenses (per rai)}

\section{SAMPLES OF THE STUDY}

Purposive samples were indicated based on 2 principles: 1) problems caused from farmers from Chantaburi Province who bought land in the area and adopted a monocropping farming practice lead to unreliability for the farmers in the area whether they should change the farming practice from an agroforestry to a monocropping system or not; 2) the definition of the terms agroforestry and monocropping are used to determine the purposive samples: 8 agroforestry households and 1 monocropping household.

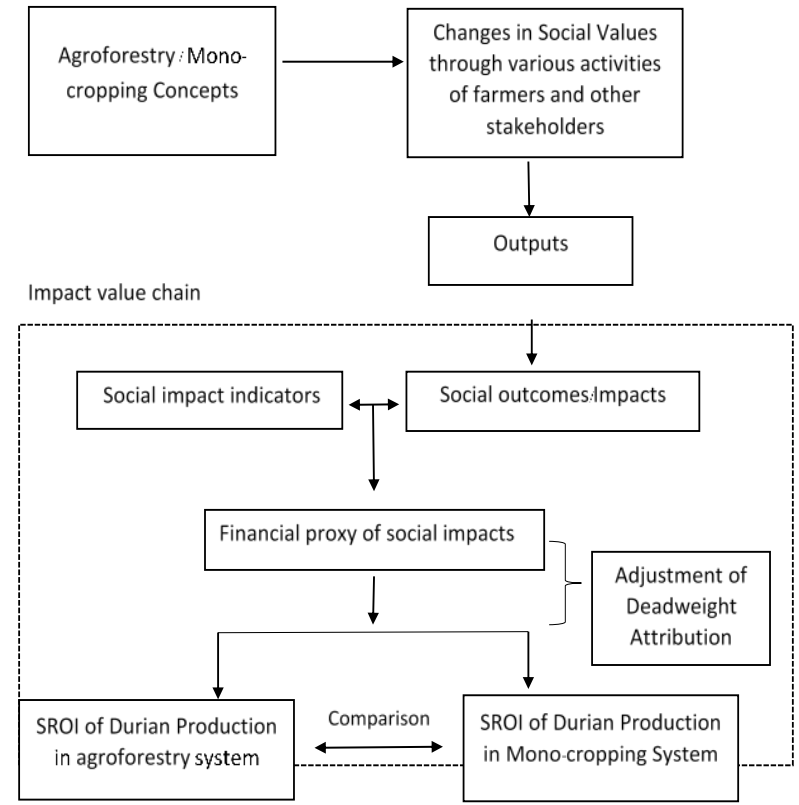

Fig. 1. Pathway concept, change, output, social outcome to calculate sroi comparing agroforestry and monocropping system.

\section{UNIT OF THE ANALYSIS}

Social impacts and the average cost per one rai $(0.0016$ square kilometer).

\section{CONCEPTUAL FRAMEWORK}

Although both agroforestry and monocropping cultivated Long Laplae Durian as the same, both concepts created different social values from variously cultivating activities. Thus, a framework of impact value chain which comprised of social outcomes which were indicated by social impact indicators calculated by financial proxy. From this framework SROI be calculated whether both concepts were different as shown in Fig. 1.

\section{RESEARCH RESULT}

The demographic characteristics of the respondents of the agroforestry system are 8 males with the average age of 57.75 years old, having junior and senior high school education. All of the respondents are married, having maximum family numbers of 11 people and a minimum of 3 people. The respondents possess the average land at 16.88 Rai (27008 square meters), while their activities from Durian farming resulted in various social impacts and financial values as shown in Table I.

TABLE I: ACTIVITIES, SOCIAL IMPACTS, SOCIAL IMPACT INDICATORS, AND FINANCIAL VALUES IN AGROFORESTRY LONG LAPLAE DURIAN FARMING

\begin{tabular}{|c|c|c|c|}
\hline Activities & Results & Indicators & $\begin{array}{l}\text { Financial } \\
\text { Proxy } \\
\text { (per year) }\end{array}$ \\
\hline $\begin{array}{l}\text {-Nurture the } \\
\text { durian trees } \\
\text { before/after } \\
\text { harvest }\end{array}$ & $\begin{array}{l}\text {-Have Freedom } \\
\text { of work and } \\
\text { being happy by } \\
\text { having this } \\
\text { freedom }\end{array}$ & $\begin{array}{l}\text {-Wages paid } \\
\text { for self and } \\
\text { family } \\
\text { members for } \\
\text { work done }\end{array}$ & $\begin{array}{l}\text {-Wages } \\
\text { (based on } \\
\text { education, } \\
\text { using the } \\
\text { rules and } \\
\text { regulations } \\
\text { from } \\
\text { Uttaradit } \\
\text { Rajabhat } \\
\text { University) }\end{array}$ \\
\hline $\begin{array}{l}\text {-Cook food } \\
\text { from the } \\
\text { agroforestry } \\
\text { farm e.g .chili } \\
\text { paste and other } \\
\text { kinds of food } \\
\text { for the guests }\end{array}$ & $\begin{array}{l}\text {-Family and } \\
\text { Relatives live } \\
\text { together }\end{array}$ & $\begin{array}{l}\text {-The value of } \\
\text { products } \\
\text { processed by } \\
\text { family } \\
\text { members or } \\
\text { relatives who } \\
\text { do not do } \\
\text { durian farming. }\end{array}$ & $\begin{array}{l}\text {-Incomes } \\
\text { from selling } \\
\text { processed } \\
\text { food with } \\
\text { expenses } \\
\text { deducted }\end{array}$ \\
\hline $\begin{array}{l}\text {-Harvest yields } \\
\text { from the } \\
\text { agroforestry } \\
\text { farm }\end{array}$ & -Have safe food & $\begin{array}{l}\text {-The numbers } \\
\text { of meals }\end{array}$ & $\begin{array}{l}\text {-The } \\
\text { numbers of } \\
\text { meals times } \\
\text { the price of } \\
\text { ready to } \\
\text { eat food } \\
\text { sold in a } \\
\text { market ( } 20 \\
\text { baht each } \\
\text { bag) }\end{array}$ \\
\hline $\begin{array}{l}\text {-Participation } \\
\text { in community } \\
\text { events }\end{array}$ & $\begin{array}{l}\text {-Relationships in } \\
\text { the community } \\
\text { are created }\end{array}$ & $\begin{array}{l}\text {-The numbers } \\
\text { of times in } \\
\text { participation in } \\
\text { community } \\
\text { events }\end{array}$ & $\begin{array}{l}\text {-The amount } \\
\text { of financial } \\
\text { aid for labor } \\
\text { support } x \\
\text { daily wage } \\
\text { (300 baht) }\end{array}$ \\
\hline
\end{tabular}




\begin{tabular}{|c|c|c|c|}
\hline $\begin{array}{l}\text {-Being invited } \\
\text { to give lectures } \\
\text { about the } \\
\text { techniques of } \\
\text { caring for } \\
\text { durian farms in } \\
\text { the } \\
\text { agroforestry } \\
\text { system }\end{array}$ & $\begin{array}{l}\text {-Local wisdom } \\
\text { about durian } \\
\text { farming in an } \\
\text { agroforestry } \\
\text { system was } \\
\text { transferred to } \\
\text { others }\end{array}$ & $\begin{array}{l}\text {-The numbers } \\
\text { of times they } \\
\text { are invited to } \\
\text { give lectures in } \\
\text { a year }\end{array}$ & $\begin{array}{l}\text {-The } \\
\text { numbers of } \\
\text { hours x the } \\
\text { hourly rate } \\
\text { ( } 600 \text { baht }) \text {, } \\
\text { as indicated } \\
\text { in the } \\
\text { Ministerial } \\
\text { Regulations }\end{array}$ \\
\hline
\end{tabular}

Sources of information: Interview

Under the social impact value chain, data obtained from the interviews were analyzed and summarized as shown in the Table II.

TABLE II: CALCULATION OF THE NET PRESENT VALUE OF THE SOCIAL RETURN ON INVESTMENT, EXPENSES FROM INVESTMENT IN AGROFORESTRY

\begin{tabular}{|c|c|c|}
\hline Year & $\begin{array}{l}\text { Social Impact } \\
\text { Value per Rai } \\
\text { (growth rate }= \\
1.09 \% \text { per year) } \\
* 1 \text { Rai }=1600 \\
\text { square meters }\end{array}$ & Summary of Calculation \\
\hline 1 & $7,345.54$ & \multirow{20}{*}{$\begin{array}{l}\text { 1.Net present value of social } \\
\text { impacts for the whole period of } \\
\text { the project, } 20 \text { years, at } 7 \% \\
\text { discount rate which was } \\
84,394.45 \text { baht per Rai } \\
\text { (1 Rai } 1600 \text { square meters) } \\
\text { 2.Expenses on activities was } \\
858 \text {. } 29 \text { baht per Rai as } \\
\text { indicated in the following } \\
\text { formula } \\
\text { 3. SROI = } \underline{84,394.45}\end{array}$} \\
\hline 2 & $7,425.61$ & \\
\hline 3 & $7,506.55$ & \\
\hline 4 & $7,588.37$ & \\
\hline 5 & $7,671.08$ & \\
\hline 6 & $7,754.69$ & \\
\hline 7 & $7,839.22$ & \\
\hline 8 & $7,924.67$ & \\
\hline 9 & $8,011.05$ & \\
\hline 10 & $8,098.37$ & \\
\hline 11 & $8,186.64$ & \\
\hline 12 & $8,275.87$ & \\
\hline 13 & $8,366.08$ & \\
\hline 14 & $8,457.27$ & \\
\hline 15 & $8,549.46$ & \\
\hline 16 & $8,642.65$ & \\
\hline 17 & $8,736.85$ & \\
\hline 18 & $8,832.08$ & \\
\hline 19 & $8,928.35$ & \\
\hline 20 & $9,025.67$ & \\
\hline
\end{tabular}

The demographic characteristics of the respondents of the agroforestry system are 1 male with the age of 52 years old, senior high school education. The respondent is married, having family numbers of 3 people. The respondents possess the average land at 20 Rai (32,000 square meters), while its activities from Durian farming resulted in various social impacts and financial values as shown in Table III.

TABLE III: ACTIVITIES, SOCIAL IMPACTS, SOCIAL IMPACT INDICATORS AND FinANCIAL VALUES IN MONOCROPPING LONG LAPLAE DURIAN FARMING

\begin{tabular}{|c|c|c|c|}
\hline Activities & "Results & Indicators & $\begin{array}{l}\text { Financial Proxy } \\
\text { (per year) }\end{array}$ \\
\hline $\begin{array}{l}\text {-Nurture the } \\
\text { durian trees } \\
\text { before/after } \\
\text { harvest }\end{array}$ & $\begin{array}{l}\text {-Have } \\
\text { Freedom of } \\
\text { work and being } \\
\text { happy by } \\
\text { having this } \\
\text { freedom }\end{array}$ & $\begin{array}{l}\text {-Wages } \\
\text { paid for self } \\
\text { and family } \\
\text { members } \\
\text { for work } \\
\text { done }\end{array}$ & $\begin{array}{l}\text {-Wages (based on } \\
\text { education, using the } \\
\text { rules and } \\
\text { regulations from } \\
\text { Uttaradit Rajabhat } \\
\text { University) }\end{array}$ \\
\hline $\begin{array}{l}\text {-Participation } \\
\text { in } \\
\text { community } \\
\text { events }\end{array}$ & $\begin{array}{l}\text {-Relationships } \\
\text { in the } \\
\text { community are } \\
\text { created }\end{array}$ & $\begin{array}{l}\text {-The } \\
\text { numbers of } \\
\text { times in } \\
\text { participatio } \\
\mathrm{n} \text { in } \\
\text { community } \\
\text { events }\end{array}$ & $\begin{array}{l}\text {-The amount of } \\
\text { financial aid for } \\
\text { labor support } x \text { daily } \\
\text { wage ( } 300 \text { baht) }\end{array}$ \\
\hline
\end{tabular}

\begin{tabular}{|c|c|c|c|}
\hline $\begin{array}{l}\text {-Being } \\
\text { invited to } \\
\text { give lectures } \\
\text { about the } \\
\text { techniques of } \\
\text { caring for } \\
\text { durian farms } \\
\text { in the } \\
\text { agroforestry } \\
\text { system }\end{array}$ & $\begin{array}{l}\text {-Monocropping } \\
\text { wisdom about } \\
\text { durian farming in } \\
\text { a monocropping } \\
\text { practice was } \\
\text { transferred to } \\
\text { others }\end{array}$ & $\begin{array}{l}\text {-The } \\
\text { numbers of } \\
\text { times they } \\
\text { are invited } \\
\text { to give } \\
\text { lectures in a } \\
\text { year }\end{array}$ & $\begin{array}{l}\text { The numbers of } \\
\text { hours x the hourly } \\
\text { rate ( } 600 \text { baht), as } \\
\text { indicated in the } \\
\text { Ministerial } \\
\text { Regulations }\end{array}$ \\
\hline
\end{tabular}

Sources of information: Interview

The Return on Investment in a monocropping system was 66.47: 1 which means when the farmers invest 1 baht in farming, they will get 66.47 baht in return. The social impacts occurred were freedom of work for the farmers, good relationships in the community, and transfer of knowledge about farming in a monocropping system as shown in the Table IV.

TABLE IV: CALCULATION OF THE NET PRESENT VALUE OF THE SOCIAL RETURN ON INVESTMENT, EXPENSES FROM INVESTMENT IN MONOCROPPING LONG LAPLAE FARMING FOR 20 YEARS, AND SROI

\begin{tabular}{|c|c|c|}
\hline Year & $\begin{array}{l}\text { Social } \\
\text { Impact } \\
\text { Value per } \\
\text { Rai } \\
\text { (growth rate } \\
=1.09 \% \text { per } \\
\text { year) } \\
* 1 \text { Rai = } \\
1600 \text { square } \\
\text { meters }\end{array}$ & Summary of Calculation \\
\hline 1 & $4,020.00$ & 1. net present value of social impacts for the \\
\hline 2 & $4,063.82$ & whole period of the project, 20 years, at $7 \%$ \\
\hline 3 & $4,108.11$ & discount rate which was $46,186.62$ baht per Rai \\
\hline 4 & $4,152.89$ & $(1 \mathrm{Rai}=1600$ square meters $)$ \\
\hline 5 & $4,198.16$ & 2. Expenses on activities was 694.82 baht per \\
\hline 6 & $4,243.92$ & Rai as indicated in the following formula \\
\hline 7 & $4,290.18$ & \\
\hline 8 & $4,336.94$ & 3.SROI = 46,186.62 \\
\hline 9 & $4,384.21$ & 694.82 \\
\hline 10 & $4,432.00$ & $=66.47$ \\
\hline 11 & $4,480.31$ & Therefore, the SROI equaled 66.47 baht for \\
\hline 12 & $4,529.14$ & 1-baht investment \\
\hline 13 & $4,578.51$ & \\
\hline 14 & $4,628.42$ & \\
\hline 15 & $4,678.87$ & \\
\hline 16 & $4,729.87$ & \\
\hline 17 & $4,781.42$ & \\
\hline 18 & $4,833.54$ & \\
\hline 19 & $4,886.23$ & \\
\hline 20 & $4,939.49$ & \\
\hline
\end{tabular}

\section{DISCUSSION}

The Social Return on Investment in agroforestry farming yielded 98.33: 1 which means when the farmers invest 1 baht in farming, the social impacts accrued a value of 98.33. The social impacts were that the farmers had the freedom to work, family members and relatives had time to spend together, community members had safe food for cooking, relationships in the community were created, and knowledge about the agroforestry farming was transferred to other farmers.

The social return on investment (SROI) in a monocropping system was at 38.86:1. This means that when the farmers invest 1 baht in farming, the social impacts accrued a value of 66.47 baht. The impacts that occurred were that farmers had 
freedom to work, relationships in the community were created, and knowledge of farming in a monocropping system was transferred to other farmers.

Agroforestry Farming yielded more SROI than a monocropping system by as much as 31.86: 1 Farming in the agroforestry system contributed to family members living together and the provision of safe food. The family members and relatives had time to spend together since the farming which adopted agroforestry practices required special care and attention on the farm. For example, the adoption of natural fertilizers, pest control with natural traps, weed cutting, pruning, nurturing and nourishing the plants and their flowers all required a labor force from family members and relatives. In agroforestry farms, there are indigenous big trees which could help to store water in the soil. Furthermore, there are a variety of plant species on the forest floor or ground layer. The farmers could use these plants for domestic consumption as well as process them and sell these products to other people. More jobs were created for family members and relatives; therefore they were not required to migrate to other areas just to get a job. The food obtained from the farm was safe from chemicals because of the use of biological controls on the farm. Therefore, the government policy should promote farming in an agroforestry system to create economically and socially sustainable development, rather than farming in a monocropping system which focuses only on economic development, increasing crop yields and incomes.

\section{CONFLICT OF INTEREST}

There is not conflict of interest. Although this research funded by Thailand Science Research and Innovation (TSRI) under Grant TSRI 026/2560, the funder has allowed to take the research for attending conference in order to publishing a research paper which is one of KPIs of the funder.

\section{AUTHOR CONTRIBUTIONS}

Chichaya changrian proposed research proposal to receive fund from the Thailand Science Research and Innovation (TSRI). After funded, Alongkorn Sukajiradet and Thavatchai Phimpho collected data and discussion the idea; Chichaya changrian analyzed the data and wrote the final research paper to sending financier. Also, Chichaya changrian wrote and presented research paper to send ICEBM 2019; all authors had approved the final version.

\section{ACKNOWLEDGMENT}

The authors are grateful to the reviewers for providing valuable comments and suggestions. This research was accomplished through the generosity of useful information from farmers, Officer of Ban Dan Na Kham Subdistrict Administration Organization and Durian's love club in Ban Dan Na Kham Subdistrict Uttaradit Province so as to creating social outcomes map to assess social return on investment until complete the research. Furthermore, researchers would like to thanks Thailand Science Research and Innovation (TSRI) and Uttaradit Rajabhat University gave an opportunity got fund and time going to conducted in Ban Dan $\mathrm{Na}$ Kham Subdistrict to finish the research.

\section{REFERENCES}

[1] M. Salleh and N. Z. Harun. (September 2013). The environmental benefits of agroforestry systems in relation to social Sustainability. The environmental benefits of agroforestry systems in relation to social sustainability. [Online]. pp. 301-317. Available: https://www.researchgate.net/publication/304259524_The_Environm ental_Benefits_of_Agroforestry_Systems_in_relation_to_Social_Sust ainability

[2] M. M.Bijarpas, T. R. Shahraji, and S. M. Limaei, "Socioeconomic evaluation of agroforestry systems - Case study: Northern Iran," Journal of Forest Science, vol. 61, pp. 478-484, 2015.

[3] S. Ekpaitoon, "Evaluation study with social compensation tools from Social Return on Investment (SROI) on social entrepreneurs: A case study of Crab Bank, Chumphon Province," Journal of Business Administration, vol. 131, pp. 61-79, 2011.

[4] W. A. Panya, "Measuring social return on investment in hotel accommodations: A case study of hotel in Bangkok and Bang Nam Phueng Homestay Community Enterprise," independent research Thammasat Business School, Thammasat University, Thailand, 2010.

[5] Social Ventures Australia Consulting. (2011). Social return on investment lessons learned in Australia. [Online]. Available: https://socialventures.com.au/assets/SROI-Lessons-learned-in-Austral ia.pdf

[6] Thailand Development Institute (TDRI). (2017). Looking at the future for 20 years. Land economy and water economy. [Online]. Available: https://tdri.or.th/2017/09/news-predictions-2035/

[7] New Economic Foundation. (October 2008). Measuring value: A guide to Social Return on Investment (SROI). [Online]. pp. 1-56: Available: https://commdev.org/wp-content/uploads/2015/06/Measuring-ValueA-Guide-to-Social-Return-on-Investment.pdf

Copyright (C) 2020 by the authors. This is an open access article distributed under the Creative Commons Attribution License which permits unrestricted use, distribution, and reproduction in any medium, provided the original work is properly cited (CC BY 4.0).

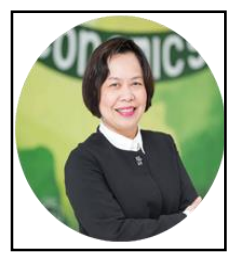

Chichaya Changrian is a lecture at Faculty of Management Science, Uttaradit Rajabhat University (URU), Thailand. She received her Ph.D. in public administration from National Institute of Development Administration (NIDA), Thailand; a master's degree in economics from Kasetsart University, Thailand; and a bachelor's degree in fisheries from Kasetsart University; a bachelor's degree in economics from Sukhothai Thammathirat Open University. Chichaya Changrian conducts research in the area of happiness, as well as the assessment of social outcome. Moreover, she is interested in cross-disciplinary studies in the areas of communication. She conducted researches with other researchers such as self-regulation for broadcasting and rating appropriateness of programs in television businesses which funded by the NBTC, Thailand.

As well as she attended a few international conferences such as in the Social and Environmental Development in the Greater Mekong Sub-region and Asia Pacific hosted by University of Kelaniya, Sri Lanka and Chiang Rai Rajabhat University, Thailand. 11st International Conference on Humanities and Social Sciences at Khon Khae University, Thailand 2015. At present, she conducts a research on the title "The Outcome and Impact Pathway Assessment of Agro Forestry Researches on East Pee Bpan Naam Mountain Range in Uttaradit Province, Thailand." Also, she is interested to expand to study mindfulness how it is able to improve work life balance in some certain level.

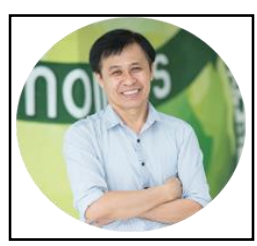

Thavatchai Phimpho is an assistant professor at Faculty of Management Science, Uttaradit Rajabhat University (URU), Thailand. He received his master's degree in economics from National Institute of Development Administration (NIDA) Thailand; the bachelor's degree in economics from Chiang Mai University, Thailand. Thavatchai Phimpho wrote a general economics and micro economics' books to improve his career path for

assistant professor.

Furthermore, he published research paper on title "Factors affecting income collection of municipally in Uttaradit Province". He always provides academic services on the topic of constructional material for agricultural business for local community, such as Nan, Phrae, Uttaradit Province, Thailand. As well as he attended a few conferences such as National academic conference in Innovation and research for sustainable development hosted by Uttaradit Rajabhat University, Thailand 2018. International 
conference on Science and Technology toward sustainable community development, hosted by Uttaradit Rajabhat University, Thailand 2018. At present, he focuses his research on construction material sales in family business and construction material areas in particular Nan Province, Thailand.

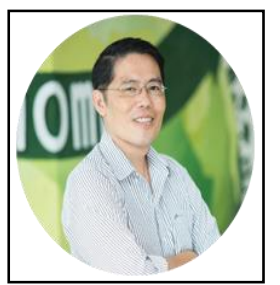

Alongkorn Sukajiradet is a lecture at Faculty of Management Science, Uttaradit Rajabhat University (URU), Thailand. He received his master's degree in economics from Chiang Mai University; and the bachelor's degree in business administration from Chiang Mai University, Thailand. Alongkorn Sukajiradet conducts research in the area of community business, as well as agricultural small business in particular Uttaradit Province, Thailand. Moreover, he always provides academic services for community business so that he accumulates a number of case studies to writing book in order to improve his career path.
As well as he attended a few conferences such as National academic conference in Innovation and research for sustainable development hosted by Uttaradit Rajabhat University, Thailand 2018. International conference on Science and Technology toward sustainable community development, hosted by Uttaradit Rajabhat University, Thailand 2018. Also, he is interested to expand to study in Thailand's stock market in order that he writes a book publishing in near future. 